\title{
ANÁliSE DO JULGAMENTO DO HABEAS CORPUS No 358.080 SOB A ÓTICA DO DIREITO FRATERNAL COMO CATEGORIA JURÍDICA CONSTITUCIONAL
}

\author{
ANALYSIS OF THE HABEAS CORPUS JUDGMENT No. 358,080 FROM THE \\ FRATERNAL LAW PURPOSE AS A CONSTITUTIONAL LEGAL CATEGORY
}

Paulo Cezar Dias ${ }^{1}$

Lucas de Holanda Martins de Castilho ${ }^{2}$

Reynaldo Soares Fonseca. Habeas Corpus no 358.080 - DF (2016/0144533-6)

Disponível em: <https://stj.jusbrasil.com.br/jurisprudencia/468401962/habeas-corpus-hc358080-df-2016-0144533-6>. Acesso em 20 de outubro de 2020.

Nascido em 28 de novembro de 1963, em São Luís do Maranhão, Reynaldo Soares da Fonseca graduou-se em direito em 1985 pela Universidade Federal do Maranhão - UFMA, na qual especializou-se em direito constitucional. Concluiu, também especialização em direito penal e direito processual penal na Universidade de Brasília - UnB, mestrado em direito público na Pontifícia Universidade Católica de São Paulo PUC-SP e doutorado em direito constitucional na Faculdade Autônoma de Direito de São Paulo - FADISP.

Fonseca iniciou a carreira jurídica como servidor do tribunal de justiça do Maranhão, foi procurador do Estado, juiz de Direito do Distrito Federal e dos Territórios, juiz federal, e em 2009 foi promovido ao Tribunal Regional Federal da $1^{\text {a }}$ Região. Em 2015 foi nomeado para o cargo de ministro do Superior Tribunal de Justiça - STJ, no qual exerce até os dias atuais.

O ministro foi o relator do acórdão proferido pela Quinta Turma do Superior Tribunal de Justiça ao julgar o pedido de Habeas Corpus $n^{\circ} 358.080$, que fora impetrado em favor de G.M.S.D, presa cautelarmente por suposta infração do crime de roubo praticado na companhia

\footnotetext{
${ }^{1}$ Pós-Doutor pela Faculdade de Direito de Coimbra-Portugal, área de Direito, Política, História e Comunicação. Doutor em Direito pela Faculdade de Direito de São Paulo -FADISP. Possui Mestrado pelo referido Centro Universitário Eurípedes de Marília. Especialista em Direito Processual e Formação em Magistério Superior pela Unisul. Graduado em Direito pelo Centro Universitário Eurípedes de Marília. Atualmente é instrutor de Mediação Judicial no TJ/SP e professor de Direito na UNIP campus Assis-SP. <pdias@tjsp.jus.br>.

Endereço para acessar este CV: http://lattes.cnpq.br/6930894647399337

${ }^{2}$ Bacharel em Análise de Sistemas e Tecnologia da Informação pela faculdade de Tecnologia de São Paulo FATEC, campus Ourinhos e atualmente cursa último semestre da graduação em Direito pela Fundação Educacional do Município de Assis-FEMA. Possui certificação em Mediação Judicial pelo TJ/SP.

Endereço para acessar este CV: http://lattes.cnpq.br/9704867759360685. <lu.hmc@ hotmail.com>.
} 
de adolescente, mediante grave ameaça, com emprego de arma de fogo, mediante concurso de pessoas, com incurso no artigo 157, § $2^{\circ}$, incisos I e II, do Código Penal, contra o acórdão proferido pelo Tribunal de Justiça do Distrito Federal e Territórios ( $\mathrm{HC}^{\circ}{ }^{\circ}$ 20160020075625), que denegou o pedido de liminar para a concessão da prisão domiciliar.

Contudo, o acórdão proferido pelo STJ reconheceu e proveu o Recurso em Habeas Corpus de substituição da pena da jovem de 19 anos. Tal decisão fundamenta-se no princípio da fraternidade, ao determinar que o juiz substitua a prisão preventiva pela domiciliar quando o agente praticante do delito for mulher e tiver filho de até doze anos de idade incompletos, conforme dispõe o inciso V, do artigo 318, do Código de Processo Penal, incluído pela Lei no $13.257 / 2016$.

A lei 13.257/2016, decorre de um resgate constitucional, vez que consta no preâmbulo da Constituição da República Federativa do Brasil o compromisso com uma sociedade fraterna, por meio da instituição de um ' Estado Democrático, destinado a assegurar o exercício dos direitos sociais e individuais, a liberdade, a segurança, o bem-estar, o desenvolvimento, a igualdade e a justiça como valores supremos de uma sociedade fraterna, pluralista e sem preconceitos, fundada na harmonia social e comprometida, na ordem interna e internacional, com a solução pacífica das controvérsias."

Na concepção do ministro Reynaldo Soares da Fonseca, o princípio da fraternidade é uma categoria jurídica que não se restringe apenas às religiões ou à moral, e redescobri-lo é essencial, diante da complexidade dos problemas sociais, jurídicos e estruturais enfrentados pelas democracias. "A fraternidade não exclui o Direito e vice-versa, mesmo porque a fraternidade enquanto valor vem sendo proclamada por diversas Constituições modernas, ao lado de outros historicamente consagrados como a igualdade e a liberdade."

Portanto, é extremamente interessante o conhecimento por parte de bacharéis, advogados, procuradores, promotores, magistrados e demais operadores do Direito, acerca da decisão proferida no acórdão, pela Quinta Turma, que ao apreciar o processo crime, conheceu por unanimidade o pedido de "Habeas Corpus"' de ofício, nos termos do Ministro Relator, a partir de uma abordagem do Direito fraternal como categoria constitucional que assegure a igualdade e a justiça como valores supremos de uma sociedade fraterna, fundada na harmonia social, conforme dispõe o preâmbulo e o artigo $3^{\circ}$ da Carta Magna.

Destarte, é de suma importância que seja valorado o princípio constitucional da fraternidade no âmbito penal, por meio da justiça restaurativa, através da humanização na hora da aplicação das penas, com o propósito de estabelecer uma sociedade fraterna mediante a 
concretização de laços de união, fundados no respeito à dignidade da pessoa humana e a igualdade de direitos entre os seres humanos. 